\title{
2
}

\section{Intermediaries, Servants and Captives: Disentangling Indigenous Labour in D. W. Carnegie's Exploration of the Western Australian Desert}

\author{
Shino Konishi ${ }^{1}$
}

In the late fifteenth century, Christopher Columbus kidnapped Caribbean people to train and use them as translators who could inform him about potential dangers and desirable commodities. The Dutch East India Company in the early seventeenth century instructed their captains to capture Indigenous peoples whenever possible for the same purpose. Then, in the late eighteenth century maritime explorers like James Cook and Matthew Flinders, on occasion, kidnapped Islander and Aboriginal people in the Pacific and Australia as punishment for perceived thefts, and as a means of asserting their authority over seemingly recalcitrant native peoples. ${ }^{2}$ Thus, for centuries European explorers felt at liberty to

1 Acknowledgements: I would like to thank the editors and participants in the Labour Lines Workshop at Deakin University, as well as Ethan Blue, Ann Curthoys, Ned Curthoys, Nicola Froggatt, Andrea Gaynor, Tony Hughes-d'Aeth, Dylan Lino, Jeremy Martens and Tiffany Shellam for feedback on earlier drafts of this paper. This work was supported by the Australian Research Council Grant DP110100931.

2 Konishi, Aboriginal Male in the Enlightenment World, 116-17, 97. 
capture Indigenous individuals as a strategy for discovering information about local environments and polities, as well as for enforcing discipline and control.

However, this practice changed in the nineteenth century with the rise of international humanitarian networks and a successful abolitionist campaign that saw both the official condemnation of slavery in the British Empire and a new rhetoric of protection. Exploration was increasingly considered as a more noble and scientific pursuit, as evident in the establishment of the Royal Geographical Society (RGS) in 1830, which 'began as a club for travellers and explorers, supported by gentleman, and [was] made intellectually respectable by scientists. ${ }^{3}$ With these changing aims, explorers, now largely overland as opposed to maritime, began to recruit and enlist Indigenous intermediaries to guide them on their expeditions, provide important intelligence about finding necessary resources and mediate with Indigenous groups encountered along the way. ${ }^{4}$ Despite this evolution in political ethos and exploration practices, by the end of the century a young British overland explorer revived the use of kidnapping, finding a new purpose for this now reviled practice as he journeyed through the Western Australian desert.

In 1896, the young adventurer David Wynford Carnegie led a privately funded expedition from Coolgardie to Halls Creek and back through the Gibson and the Great Sandy deserts. While Robert Austin (1854), John Forrest (1869 and, with his brother, Alexander Forrest, in 1870 and 1874), Peter Egerton Warburton (1872-74) and Ernest Giles (1873, 1873-74, 1875 and 1876) had all explored Western Australian deserts before him, Carnegie was the first to traverse the desert from south to north and back again. He also travelled further through the desert than any of his predecessors. However, now he is best remembered for kidnapping Aboriginal people as a means of finding water, an extreme practice that none of his predecessors had undertaken. ${ }^{5}$ In his study of

3 Stoddart, "The RGS and the "New Geography", 192.

4 See, for example, Burnett, "It is Impossible to Make a Step without the Indians", 3-40; Driver and Jones, Hidden Histories of Exploration; Fritsch, "You Have Everything Confused and Mixed Up", 87-101; Konishi, Nugent and Shellam, Indigenous Intermediaries; Shellam, Nugent, Konishi and Cadzow, Brokers and Boundaries.

5 John Forrest later reported that during his expedition he found the natives of very little use to him', and that he 'had always with him civilized natives of a high standard of intelligence, who were equally as well versed in the habits and ways of the bush natives as they were in the habits and customs of white men'. 'The Canning Enquiry: Royal Commission's Report', Kalgoorlie Western Argus, 25 February 1908, 34. 
explorers and Aboriginal guides, Henry Reynolds explained that, 'when prospects became grim', Carnegie resorted to capturing an Aboriginal man and woman-the former being first 'run down and subjected to prolonged thirst' - so that they could lead him to water. ${ }^{6}$ Dane Kennedy also discussed Carnegie, who 'repeatedly rode down Aborigines, chained or tied them up, and denied them food and drink until they had guided his party to water', and similarly concluded that to 'kidnap an indigene was an act of desperation'?

Though critical, both Reynolds and Kennedy nonetheless rationalised Carnegie's use of kidnap, suggesting that it was dire emergency that drove him to hold Indigenous people captive. Yet, as David Goodman asserts in regard to gold rush history, historians should not naturalise or unquestioningly take for granted certain behaviours and trajectories such as the so-called 'acquisitive instinct that led so many to rush after gold'. Instead, they should investigate the 'particular way of thinking' that underpinned such actions. ${ }^{8}$ Rather than rationalise Carnegie's kidnapping of Indigenous people as exceptional — that is, as 'act[s] of desperation'we should seek to understand both the particular circumstances and the broader colonial mentality about Aboriginal people and labour that led Carnegie to take what seems like an extreme course of action, both to us today and also to other explorers in the nineteenth century.'

This chapter seeks to investigate the 'particular way of thinking' that led Carnegie to use kidnap and captivity to coerce Aboriginal people into finding water for his expedition. Rather than focusing on the singular event, I examine Carnegie's earlier forays prospecting in the Western Australian goldfields and his developing views about Aboriginal people

6 Reynolds, 'The Land, the Explorers and the Aborigines', 222.

7 Kennedy, The Last Blank Spaces, 165.

8 Goodman argues that historians, unquestioning acceptance of the gold rush mentality is even more problematic because 'many contemporaries were indeed alarmed at the rushing after wealth at the expense of all that made it meaningful—family, community, social order'. Goodman, 'The Gold Rushes of the 1850s', 173.

9 Morison argues that he was 'subsequently criticised severely' for 'captur[ing] Aboriginals'. Morison, 'Carnegie, David Wynford (1871-1900)'. When the Western Australian Department of Lands and Surveys surveyor Alfred Canning used the same strategy in 1906, it sparked the Royal Commission to Enquire into the Treatment of Aboriginal Natives by the Canning Exploration Party (1908), which discussed Carnegie's example at length. Although the enquiry found that the 'capturing and chaining of natives under any circumstances is undoubtedly unlawful', they eventually decided that it was 'absolutely necessary' to ensure their survival, especially following the Calvert expedition in which two men perished. 'The Canning Enquiry: Royal Commission's Report', Kalgoorlie Miner, 22 February 1908, 8. 
and their potential as a labour source. I argue that Carnegie's approach was not just a survival strategy, but also reflected changing colonial ideas about Indigenous labour and the coercive measures that were believed necessary to harness it in Western Australia. Moreover, this chapter considers how the justification for such coercive carceral strategies were exacerbated by the mobile exigencies of exploration. Given that Carnegie moved through Aboriginal country rather than settling in a particular place, his encounters with Indigenous individuals were short-lived. Thus, Indigenous people remained alien and unfamiliar to him, which arguably encouraged his callous attitude towards both them and their precious water.

\section{Indigenous Labour in Colonial Western Australia}

Since the 1970s, historians have observed that Aboriginal labour was integral to the development of Western Australia's colonial economy, due to its immense size, sparse population, challenging environmental conditions and the limited availability of convict labour. Convict transportation to the colony did not begin until 1850, and the employment of both convicts and ex-convicts was 'banned north of the Murchison River', which meant that the northern industries-pearling and pastoralism-were dependent on Aboriginal labour in the nineteenth century. ${ }^{10}$ As John Host and Jill Milroy among others have observed, another crucial factor in relation to this dependence was the 'colonial mindset that saw the exploitation of Aboriginal labour for little or no reward as a perfectly acceptable practice'. ${ }^{11}$ The northern Indigenous labour force was not only largely unpaid, but also largely unfree.

Within capitalist economies, unfree labour refers to labour provided by workers who are 'separated from the means of production and subsistence' and unable to freely 'commodify their labour' for wages. Unfree labour includes categories of slavery, in which workers themselves become commodities to be bought (i.e. not just their labour), and forced or coerced labour, in which the labour relationship is either entered into

10 Host and Milroy, 'Towards an Aboriginal Labour History', 10.

11 Host and Milroy, 'Towards an Aboriginal Labour History', 10. 
under duress' or is 'entered into freely but then becomes coercive'. ${ }^{12}$ Sean Winter explains that coerced labour is 'a very specific form of exploitation where workers are controlled within institutional and legal structures that limit their freedom and their labour is extracted through threats of negative sanction'. He adds that the coercion can be 'economic, mental, emotional, social and physical' in nature, but that, 'crucially, the worker is not free to withdraw their labour if they wish'. ${ }^{13}$

The most obvious use of coerced labour in Western Australia was in the early pearling industry that began in the Pilbara in 1867 and was widely known for 'blackbirding', or kidnapping, Aboriginal people from across the north who were then 'alienated from their home country and forced to dive for shell'. Not only was this life-threatening work, with many suffering from the 'bends' or shark attack, but also Aboriginal divers faced being marooned on island camps to prevent them returning to their homelands so that they could be put to work the next season. ${ }^{14}$ The terrible abuse suffered by Aboriginal divers was widely known and, in the 1870s, Governor Frederick Weld 'passed a series of Acts ... prohibiting kidnapping .... and the employment of women'. In 1880, a more stringent Act was passed regulating the age of divers and their conditions, and 'requiring they be returned home after six months'. Yet, as Ann Curthoys has shown, pearlers reacted strongly against these new regulations, and so the Acts were amended by Weld's successor Governor William Robinson to allow a return to harsher and more exploitative practices. By 1886, between 600 and 700 Aboriginal people were employed in the industry. ${ }^{15}$ Further, many pearlers had connections to the emerging pastoral industry, which also depended on unfree Aboriginal labour; between 1881 and 1901, the number of Aboriginal people working on stations increased fivefold to approximately $12,000 .^{16}$

The exploitation of coerced Aboriginal labour was enabled by the frontier violence that drove people off their lands and made them dependent on rations, and by the punitive legislation that criminalised Indigenous resistance to pastoral expansion, including the spearing of livestock and retaliation for settlers' abuse of Aboriginal women, which created a large workforce of Aboriginal prisoners. These prisoners were either

12 Strauss, 'Coerced, Forced, and Unfree Labour', 3-4.

13 Winter, 'Coerced Labour', 3.

14 Winter, 'Coerced Labour', 8.

15 Curthoys, 'Indigenous Dispossession', 218.

16 Host and Milroy, 'Towards an Aboriginal Labour History', 11. 
'warehoused' at Rottnest Island where they could no longer disrupt colonial expansion in their homelands ${ }^{17}$ or forced to work in chain gangs 'roadmaking, quarrying stone, protecting river banks, and reclaiming marshy lands', saving the government thousands of pounds in infrastructure costs. ${ }^{18}$ Moreover, Aboriginal prisoners were widely forced to wear neck chains, even while locked up in gaol or labouring in the extreme heat. This practice, though censured, was justified by claims such as Western Australian Chief Protector of Aborigines Henry Princep's statement in 1901 that:

A native is so lithely made that he can get out of a ring fastened with all reasonable tightness round his waist, and that if put around his ankle he can easily get at it with his hands ... that it is not effective. ${ }^{19}$

In spite of metropolitan criticisms from London's and Australia's urban centres, which led to various royal commissions and government inquiries, as well as the colonial government's repeated attempts to reform and regulate the employment of Indigenous people, in the late nineteenth century, Aboriginal people in remote parts of Western Australia became increasingly vulnerable to coercive and carceral labour conditions. As Curthoys has shown, this was because of the entwined economic and political interests of pearlers, pastoralists, government agents and the police that sought to dispossess Aboriginal people of their lands and capture and exploit their labour. ${ }^{20}$

Thus, while humanitarian concerns about the protection of Indigenous peoples circulated throughout metropolitan centres, including in scientific societies like the RGS, which sponsored many nineteenthcentury expeditions, in remote Western Australia, local conditions fostered a colonial mentality that Aboriginal labour could only be harnessed under duress, and literally with chains. As the former desert explorer and Western Australian premier Sir John Forrest came to argue in 1907, 'the people in Western Australia "knew more about the matter than the people of England" and that "chaining Aboriginals [sic] by the

17 Winter, 'Coerced Labour', 7.

18 'W.A. Prisons, Interesting Report, Prison Labour, Native Prisons', The Daily News (Perth), 3 September 1909, 6, cited in Harman and Grant, “Impossible to Detain without Chains”?, 166-67.

19 Henry Princep, 'Aborigines Department Report for Financial Year Ending 30 ${ }^{\text {th }}$ June 1901', Perth, W. Alfred Watson, Government Printer, 1901, 5, cited in Harman and Grant, "Impossible to Detain without Chains"?', 164-65.

20 Curthoys, 'Indigenous Dispossession'. 
neck was the only effective way to prevent their escape"'. ${ }^{21}$ As we will see, Carnegie was arguably both a product of, and contributor to, this more mercantile and mercenary colonial mentality. In his expedition through the Western Australian desert, Carnegie flouted the new metropolitan ideals of scientific exploration, and returned to an older, more exploitative, practice of violently capturing and incarcerating Indigenous people to force them to act as guides.

\section{Carnegie's Early Expeditions}

The honourable David Wynford Carnegie, the fourth son of the Sixth Earl of Southesk, arrived in Western Australia from London, via Melbourne, in September 1892 at the age of $21 .^{22}$ With his friend Lord Percy Douglas he was determined to make his own name and fortune. Just as he landed, the news of Arthur Bayley and William Ford's discovery of gold at a still 'unnamed' district reached Albany. Carnegie quickly joined the gold rush and set off towards the newly minted town of Coolgardie. ${ }^{23}$ On his journey from King George Sound to Perth, and then on to the goldfields, he noticed that the region was suffering a 'water-famine', and that water was the driving preoccupation of everyone he observed. ${ }^{24}$ Carnegie shared the road with camel caravans and horse-drawn wagons transporting water to the fledgling township that, upon arrival, were 'swarm[ed] by men brandishing empty waterbags'. On his journey, he saw both 'men and beasts' driven 'mad with thirst'. He also observed a landscape cleared to allow "dry-blowing" operations', the local process for separating gold from alluvial soil without the need for water. As Carnegie often repeated, "'Prospecting" is generally taken to mean searching for gold', yet:

[In] Western Australia in the hot weather it resolves itself into a continual battle for water, with the very unlikely contingency that, in the hunt for a drink, one may fall up against a nugget of gold or a gold-bearing quartz reef. ${ }^{25}$

21 'Treatment of Aboriginals: Sir John Forrest's Opinion', Morning Post (Cairns), 13 July 1907, 3, cited in Harman and Grant, "Impossible to Detain without Chains"?', 172.

22 Carnegie had entered the Royal Indian Engineering College where he studied maths and surveying; however, due to his 'high animal spirits', he left before finishing and impulsively travelled to Ceylon to work on a tea plantation, which he immediately found 'uncongenial'. He then sailed to Australia with his friend Lord Percy Douglas, Marquis of Queensbury. H. M. Carnegie, 'Introduction', vii-viii.

23 Carnegie, Spinifex, 2; Morison, 'Carnegie, David Wynford (1871-1900)'.

24 Carnegie, Spinifex, 8.

25 Carnegie, Spinifex, 70. 
Carnegie spent his first year or so in Coolgardie working at the Bayley's Reward Mine. In his free time, he 'por[ed] over the map of the Colony, longing and longing to push out into the vast blank spaces of the unknown'. ${ }^{26}$

By March 1894, Carnegie's friend, Douglas, had secured Londonbased investors to establish a mining exploration company to support Carnegie's prospecting expedition to the Hampton Plains, which lay east and north-east of Coolgardie. ${ }^{27}$ This was to be very modest in scope, entailing a single offsider, Gus Luck, a French Alsatian prospector with cameleering experience and a smattering of local Aboriginal words; three camels; and 'scanty facilities for carrying water' ${ }^{28}$ Shortly after setting out, the two men met returning parties who warned them that 'every water was dry'. ${ }^{29}$ On 29 April, a month into their journey and a week since they had filled their water supplies, they heard a 'shrill "coo-oo"' and were 'startled to see some half-dozen natives gazing' at them. At that moment, one of the camels bellowed and scared the Aboriginal men who quickly ran off. In the heat of the moment, Carnegie and Luck chased them, and the latter managed 'to stop a man'. ${ }^{30}$ The man appeared to be:
A fine, well made chap, short but thickset, with curious marks cut $\&$ gashed into the flesh on his ribs[,] a belt of plaited reeds round his waist and a 'sporan' [sic] of grass in front.

He did not 'seem frightened' of Carnegie, but was scared of the 'camels which he would not approach'. ${ }^{31}$ After giving him some food, which Carnegie first tasted to 'put him more at ease', Luck tried to question the man about water. Finally, he seemed to understand. Repeatedly saying 'ingup', he led them to a small granite rock and seemingly pointed to a soak or rock hole. While Carnegie and Luck inspected it, the man 'escaped into the scrub and was soon lost to view'. ${ }^{32}$ That night, Carnegie and Luck began digging in the rock hole and, over the next two days, collected five or six gallons of water. Perhaps the Aboriginal man's decision to take the explorers to the water source was an act of reciprocity for the food he had been given; it may also have been a pragmatic effort to give the strangers ingup so as to encourage them to quickly pass through his

26 Carnegie, Spinifex, 15; Peasley, In the Hands of Providence, 8.

27 H. M. Carnegie, 'Introduction', ix; Peasley, In the Hands of Providence, 9.

28 Carnegie, Spinifex, 41.

29 Carnegie, Spinifex, 35.

30 Carnegie, Spinifex, 47.

31 Carnegie, Diaries, vol. 1, 14

32 Carnegie, Spinifex, 47. 
country. ${ }^{33}$ Yet, for Carnegie, it planted a seed for his future coercive watergathering strategies. Carnegie and Luck continued on their explorations and, though they found a gold-bearing quartz reef, it was too remote to be promising. On 22 June, they returned to Coolgardie ${ }^{34}$ and Carnegie continued to Perth.

However, Carnegie did not relinquish his gold ambitions. In November 1894, he returned to Coolgardie after receiving financial support from a syndicate for a second expedition. This time his crew included Jim Conley, an American who had field experience in South Africa and on the Yukon, and Paddy Egan, an 'Irish-Victorian' who was experienced in the Western Australian goldfields. Carnegie purchased three new camels and, significantly, portable condensers that could render salt water potable. ${ }^{35}$ He hoped the condensers would alleviate his need to find water in the desert. On 10 November the party set out from Coolgardie, travelling initially along the Twenty-Five Mile Road, before heading east to where he had previously seen some promising country. ${ }^{36}$ Carnegie soon realised that the condensers were not the saviours he anticipated. Shortly after setting out, the party set up the condensers and discovered how laborious they were to run; the process entailed finding, chopping and carrying wood to fire the boilers, which demanded 'constant attention', stoking the fires and decanting the desalinated water as it 'slowly trickled from the cooling tray'. Between maintaining the condensers and tending to the camels, Carnegie learned that he and his crew had little time left to prospect for gold. He would never use them again on another expedition. When the condensers' boilers finally burned through, the frustrated expedition decided to again return to Coolgardie, arriving on 30 December less than two months after they set out.

After a quick stay to reprovision, the expedition set out on 4 January 1895, heading to Mount Darlôt where gold had just been discovered. This time they were successful in their mission for, on 17 February, Carnegie and Paddy found gold. Ironically, it was while Carnegie was out taking a walk. He mused: 'It seems the simplest thing in the world to find a gold mine- that is ... after you have found it!' ${ }^{37}$ After marking out the find,

33 Don Baker uses the term 'passing on' to describe Aboriginal people who were anxious to urge explorers through their lands into neighbouring territory as quickly as possible. Baker, 'Wanderers in Eden', 10.

34 Carnegie, Spinifex, 65.

35 Carnegie, Spinifex, 69-71.

36 Carnegie, Spinifex, 70.

37 Carnegie, Spinifex, 107. 
Carnegie raced alone back to Coolgardie to obtain a mining licence, eventually establishing a mine; however, his investors soon decided to sell it. ${ }^{38}$ Carnegie was not too upset by this turn of events, as, having achieved his desire to find gold, he now sought fame as an intrepid explorer. Building on the east-west desert explorations of John Forrest and Peter Egerton Warburton, he planned an expedition journeying from south to north..$^{39}$ Significantly, he had learned from his desert experiences that he would stand a greater chance of success if he used Aboriginal people.

\section{Aboriginal Labour in the Goldfields}

Many scholars have explained that, during the colonial period, Aboriginal people had few economic options, as they were dispossessed of their lands, which were expropriated and violently defended by settlers and the state, and often despoiled by colonial industries and livestock. ${ }^{40}$ Robert Castle and Jim Hagan argue that many Aboriginal people were forced to 'depend on handouts from their conquerors' or 'activities regarded as criminal such as stealing, begging and prostitution', or else make-do by providing labour to colonists. ${ }^{41}$ Upon first arriving at the new township of Coolgardie in 1892, Carnegie observed that the local Wongatha people were a visible presence in the town, which comprised little more than a general store and post office run by Mr Benstead, who served as postmaster, butcher and storekeeper. ${ }^{42}$ In this nascent town, where drought and the difficulty of finding gold ensured that hardship was widespread among the prospectors, few handouts were given to the Wongatha people, who nonetheless appeared to turn to begging. Carnegie was shocked by the appearance of the 'famine-stricken' Wongatha, observing that in the drought 'not a living thing was to be found in the bush', so 'without begging from the diggers I fail to see how they could have lived'. ${ }^{43}$

38 He travelled back to Coolgardie on his own to obtain the licence and, during this journey, contracted typhoid fever. Upon arriving in Coolgardie, he then went to Perth to convalesce at the home of Colonel Fleming. H. M. Carnegie 'Introduction', xi.

39 He drew up a map of his extant journeys for the Western Australian surveyor-general, and then went home to Britain for three months before returning to Western Australia in April 1896. H. M. Carnegie, 'Introduction', xi-xii.

40 Keen, Indigenous Participation in Australian Economies; Fijn et al., Indigenous Participation in Australian Economies II.

41 Castle and Hagan, 'Settlers and the State', 24.

42 Carnegie, Spinifex, 8.

43 Carnegie, Spinifex, 10. 
Yet, Carnegie's account of begging cannot be taken at face value. For instance, as Lynette Russell reminds us, what Europeans construed as begging was not merely an 'opportunistic strategy for the acquisition of money, food and other goods', but instead served as 'a viable, justifiable form of economic engagement [for Aboriginal people]-a kind of reciprocity for what they had lost'. ${ }^{44}$ Further, Fred Cahir, in his study of Koories on the Victorian goldfields, observed that 'soliciting in this period' was not 'primarily driven by poverty alone', since many Koories 'were still largely self-sufficient, and when moments of poverty occurred, implored their white brethren for meaningful paid work and keep, rather than simply begging for food and money. ${ }^{45}$ Similarly, in the Western Australian goldfields, Aboriginal people evidently sought to exchange food for their labours in collecting water; however, Europeans generally dismissed this as begging. Carnegie reported that, in Coolgardie, 'hardly a day passed but what one was visited by these silent, starving shadows' who would implore the miners to "'Gib it damper", and that 'seldom' were these requests 'made in vain'. Yet, he elaborated that, in 'appreciation no doubt of the kindness shown them, some of the tribe volunteered to find "gabbi" [water] for the white-fellow in the roots of a certain gum-tree', most likely red mallee roots, which held water that could be drained into a coolamon or other vessel. ${ }^{46}$ To Carnegie, this exchange was essentially one of European charity and Indigenous gratitude, and not a legitimate transaction of goods for services. ${ }^{47}$ Nor did he see the Wongatha's laborious collection of mallee roots as a form of work.

This framing of Aboriginal work as begging is part of the larger conceptual discourse defined by Claire Williams and Bill Thorpe as 'colonised labour'. They see this form of labour as a product of imperialism and colonialism in which 'Aboriginal and Islander territory and people' were ensnared 'in a racist social relationship' with colonists. ${ }^{48}$ The assumed racial and cultural superiority of the colonists meant that the use of colonised labour was riddled with contradictions, as it was both desired

\footnotetext{
44 Russell, “'Tickpen”, "Boro Boro”, 27.

45 Cahir, Black Gold, 15.

46 Carnegie, Spinifex, 11. Ian Bayly explains that Aboriginal people across Australia could obtain water from the cut tree roots of red mallee, which grows in the alluvial soil of the wheatbelt, as well as the desert kurrajong, needle bush, desert oak and water bush. Bayly, 'Review of How Indigenous People Managed for Water', 22-23.

47 For a discussion of this enduring Western blindness to Aboriginal labour see Jon Altman's chapter in this collection.

48 Williams and Thorpe, Beyond Industrial Sociology, 88-107.
} 
and derided. According to Williams and Thorpe, the 'colonised worker is alternately valued as a labour commodity but also devalued, employed and unemployed, paid but mostly unpaid, integrated but mostly marginalised'. ${ }^{49}$

Perhaps the most egregious and troubling form of colonised labour evident on the goldfields was the exploitative use of 'black-boys', as Carnegie referred to them. As Kennedy observes, many explorers throughout Australia and Africa 'picked up indigenous youths to assist them in their endeavours', valuing them for their apparent tractability, which was a consequence of their vulnerability as 'deracinated' individuals. In Australia, Aboriginal youths were 'put to work as stock herders, domestic servants, and more', and 'often physically abused and sometimes sexually exploited'. ${ }^{50}$ The employment of Aboriginal children in the nineteenth century was, for the most part, unregulated, and protection boards at that time only kept minimal records that rarely included workers' ages. Consequently, the histories of such children are only known through ad hoc references to individual children employed by colonists as domestic servants and labourers, often described as 'companions' in archival sources and published journals and memoirs. Further, according to Shirleene Robinson, Aboriginal children were particularly vulnerable to exploitation as they were not subject to the admittedly limited mechanisms that protected European children from abuse. ${ }^{51}$ In addition to the physical abuses and trauma suffered by Aboriginal child workers in the nineteenth century, their labour as servants was not even acknowledged as work, as evident from the title 'companions'. Even in frontier locations, Carnegie met settlers and itinerants who had Aboriginal child companions; however, like other colonists, he perceived their domestic labour not as employment but as a form of tutelage in the benefits of civilisation.

49 Williams and Thorpe, Beyond Industrial Sociology, 99. Thorpe elaborated on this in his Colonial Queensland: Perspectives on a Frontier Society, maintaining that 'colonised labour' is 'subordinate to all other forms of labour' such as migrant labour and convict labour, which perhaps explains its invisibility to mainstream Australian society. More significantly, this conception of labour is underpinned by the colonists' attempt to 'expropriate as much land as possible' and the twin desires to 'eliminate Aborigines altogether' and to use Indigenous people as a 'source of readily available, exploitable labour'. Thorpe, Colonial Queensland, 65-66.

50 Kennedy, The Last Blank Spaces, 171-72, 175.

51 Robinson's research in late nineteenth-century Queensland, which bore many similarities to Western Australia in terms of frontier economies and attitudes towards Aboriginal people, reveals widespread anecdotal evidence that Aboriginal children were kidnapped from their families, had been witness to frontier violence, and were subject to physical and sexual abuse, as indicated by reported instances of pregnancy and venereal disease. See Robinson, 'The Unregulated Employment of Aboriginal Children', 1-15. 
As soon as Carnegie arrived in Coolgardie he met Sylvester Browne and Gordon Lyon' ${ }^{52}$ who had with them a 'small black-boy whom they tried in vain to tame'. Carnegie did not explain how they came to have the child in their care, only mentioning that he was a local Wongatha boy who 'stood a good deal of misplaced kindness' and yet still 'ran away to the bush'. ${ }^{53}$ When Carnegie returned to Coolgardie in 1896 he stayed with Tom and Gerald Browne, reporting that the latter possessed a boy 'taken away from a tribe' east of Lake Darlôt. Unlike the first boy he met, Carnegie exclaimed that this 'little chap' was 'as spruce and as clever as any white boy of the same size..$^{54}$ On his final expedition in 1896, Carnegie benefited directly from the labour of Aboriginal youths, as the party enlisted Warri, a 16-year-old 'aboriginal boy from the McDonnell Ranges in Central Australia'. Warri was the 'black-boy' of Joe Breardon, an Australian 'born and bred in the bush' who Carnegie recruited for his expedition, and who had ostensibly trained Warri since the age of six to ride and track. Carnegie immediately perceived Warri as a 'distinct acquisition' for the expedition, for he had initially intended on 'getting a discharged prisoner from the native jail at Rotnest [sic]' to serve as a guide, so was happy to substitute Warri because 'prison life is apt to develop all [the Aboriginal prisoners'] native cunning and treachery'. ${ }^{55}$ In April 1897, towards the end of the expedition, Carnegie also temporarily acquired some young boys from Sturt Creek, one of whom Carnegie named Tiger and used as a translator and labourer until he absconded..$^{56}$ Reflecting on the various 'black-boys' he had encountered in Western Australia led Carnegie to muse not on how such children came to be wards of settler men, but on the educability of Aboriginal people:

Great tact is necessary in the education of the aboriginals. Neglect turns them into lazy, besotted brutes who are of no use to anybody; too kind treatment makes them insolent and cunning; too harsh treatment makes them treacherous; and yet without a certain amount of bullying they lose all respect for their master, and when they deserve a beating and do not get it, misconstrue tenderheartedness into fear. The 'happy medium' is the great thing; the most useful, contented, and best-behaved boys that I have seen are those that receive treatment similar to that a highly valued sporting dog gets from a just master; 'to pet' stands for 'to spoil'. ${ }^{77}$

52 Carnegie, Spinifex, 9. See also Simpson, 'Bayley, Arthur Wellesley (1865-1896)'.

53 Carnegie, Spinifex, 11.

54 Carnegie, Spinifex, 153.

55 Carnegie, Spinifex, 149.

56 Carnegie, Spinifex, 365-75; Carnegie, Diaries, vol. 3, 64.

57 Carnegie, Spinifex, 153-54. 
Carnegie's account conspicuously masks the labour performed by Aboriginal youths. In his eyes, the Aboriginal youths seemed more akin to work animals - who the colonial master was obliged to discipline and train-than employees. In turn, as Angela Woollacott has persuasively argued, the patriarchal control of indentured and Aboriginal labour played a crucial role in colonial conceptions of white settler manhood, defined by status that resulted from the control of bonded labour, be it convict, indentured or Indigenous. ${ }^{58}$ Carnegie's account suggests that this form of white, settler, masculine identity was not just the privilege of landholding farmers and pastoralists of British extraction, such as those Woollacott describes, but also could be adopted by men with few possessions other than a 'black-boy'.

\section{Carnegie's 1896 Expedition}

In 1896, Carnegie organised his most ambitious expedition. To follow the likes of John Forrest, who explored an inland route through the desert from Perth to Adelaide in 1870, and Peter Egerton Warburton who crossed the desert in the other direction in 1872-74, Carnegie planned to travel through the Western Australian desert from south to north, investigating new lands between Forrest's and Warburton's travels for signs of gold and a potential new stock route. For this purpose, he assembled a new crew. In addition to Breardon and Warri, Carnegie employed Godfrey Massie and Charles Stansmore, and purchased eight packing camels and a riding camel.

The expedition set out on 9 July and entered the desert on 23 July. Over the course of the expedition, the party spent 13 months in the desert and travelled more than 3,000 miles, ${ }^{59}$ further than any previous European explorer had travelled through the Australian desert. More significantly, Carnegie increasingly turned to capturing Aboriginal people as a means of finding water, employing more systematic and coercive methods of detaining his captives, and eventually giving up any pretence of compensating them for their knowledge, labour or suffering.

58 Woollacott, 'Frontier Violence and Settler Manhood', 1-11. For more on the treatment of indentured labourers see Tracey Banivanua Mar's chapter in this collection.

59 Carnegie, Spinifex, 430. 
DAVID`W. CARNEGIE. WARRI.

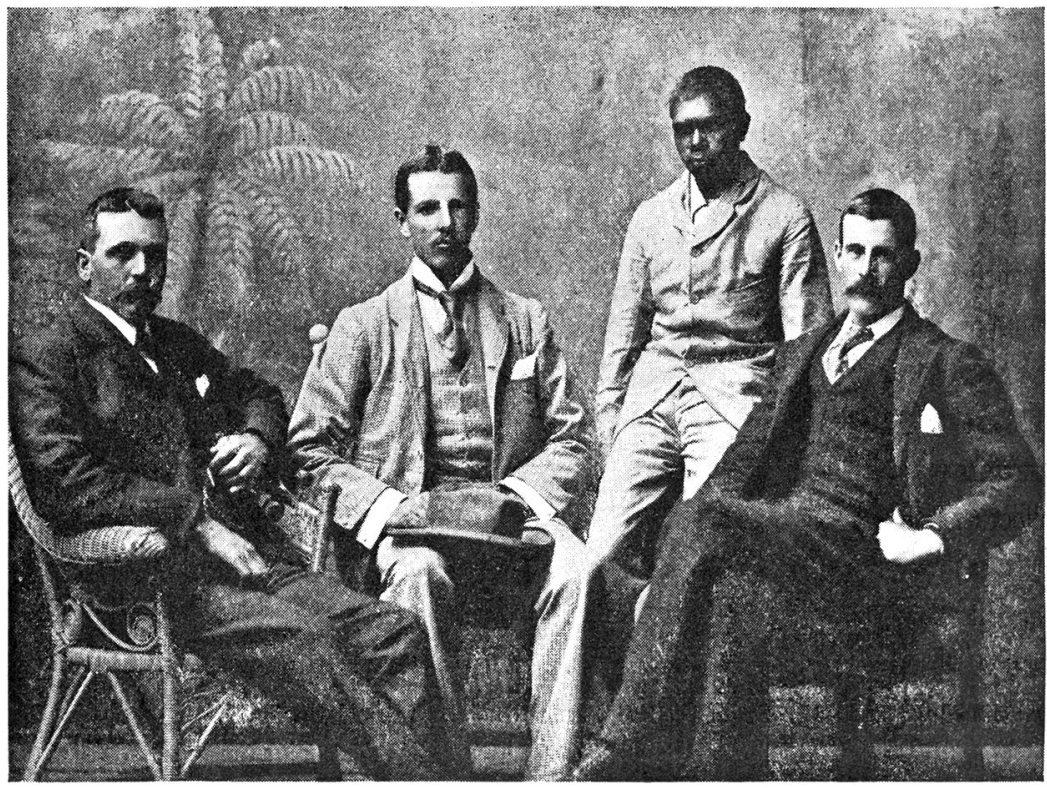

JOSEPH A. BREADEN.

GODFREY E. MASSIE.

Figure 2.1: 'Group of explorers'.

Source: Carnegie, Spinifex, 352.

On 7 August 1896, nine days after the explorers had last found water, Warri spotted footprints that the party decided to follow, assuming that there 'must be water at the end of them'. After a few false starts, they eventually spied an Aboriginal man on 9 August and Breardon shouted: 'Catch him.' They gave chase and captured the terrified man. Through gestures, they communicated their desire for water. The man seemed to understand their demand and a 'strange procession started':

Guarded on one side by Breardon, I on the other, we plied our new friend with salt beef, both to cement our friendship and promote thirst, in order that for his own sake he should not play us false. ${ }^{60}$

60 Carnegie, Spinifex, 189. 
As with the man Luck had captured on the previous expedition, they offered their captive food, albeit deliberately salty food, and did not use any physical restraints. When he finally led them to a rock hole, Carnegie and Breardon ran ahead of him, excited by the prospect of water, giving the man a chance to escape. However, upon discovering that the rock hole was dry, they quickly chased him down, this time tying him up with rope and 'watch[ing] him in turn all through the night' ${ }^{61}$ Distressed by his captivity, the man, who Carnegie 'named' King Billy (possibly after one of his camels), stayed awake all night, trying various strategies to escape:

He would lie still with closed eyes for a time, and then make a sudden struggle to wrench the rope away from his captor; then stealthily with his foot he tried to push the rope into the fire; then he started rubbing it on the rock on which we lay; and last of all his teeth were brought into use.

The next morning Carnegie 'confess[ed] that I saw with delight the evident feelings of thirst that before long overcame him — the salt beef had done its duty'. Driven to desperation, 'King Billy' led them to an underground cave called 'Murcoolia Ayahteenyah'. ${ }^{62}$ Carnegie and his men were overjoyed to discover it was a soakage, which Carnegie renamed Empress Spring after Queen Victoria. With little regard for the Aboriginal people who depended on this water supply, the expedition spent four days in the cave, initially making King Billy 'bal[e] water with a meat tin into a bucket', until they watered their camels and replenished their water supplies.

Carnegie did not admit to himself that they had kidnapped the man. Upon gifting King Billy some clothing and the lid of a meat tin, Carnegie asserted that the man 'seemed to warm towards us $\&$... became quite at home'. ${ }^{63}$ However, by the 'second morning he had gone', which Carnegie lamented for King Billy had 'become very useful, carrying wood and so forth with the greatest pleasure'. Even after King Billy escaped, Carnegie still claimed that he treated the man well:

I fancy that his impressions of a white man's character will be favourable; for never in his life before had he been able to gorge himself without having had the trouble of hunting his food. ${ }^{64}$

61 Carnegie, Spinifex, 189

62 Carnegie, Diaries, vol. 3, 20. Carnegie removed the Aboriginal name of the cave from his word list in in the published account.

63 Carnegie, Diaries, vol. 3, 19.

64 Carnegie, Spinifex, 198. 
2. INTERMEDIARIES, SERVANTS AND CAPTIVES

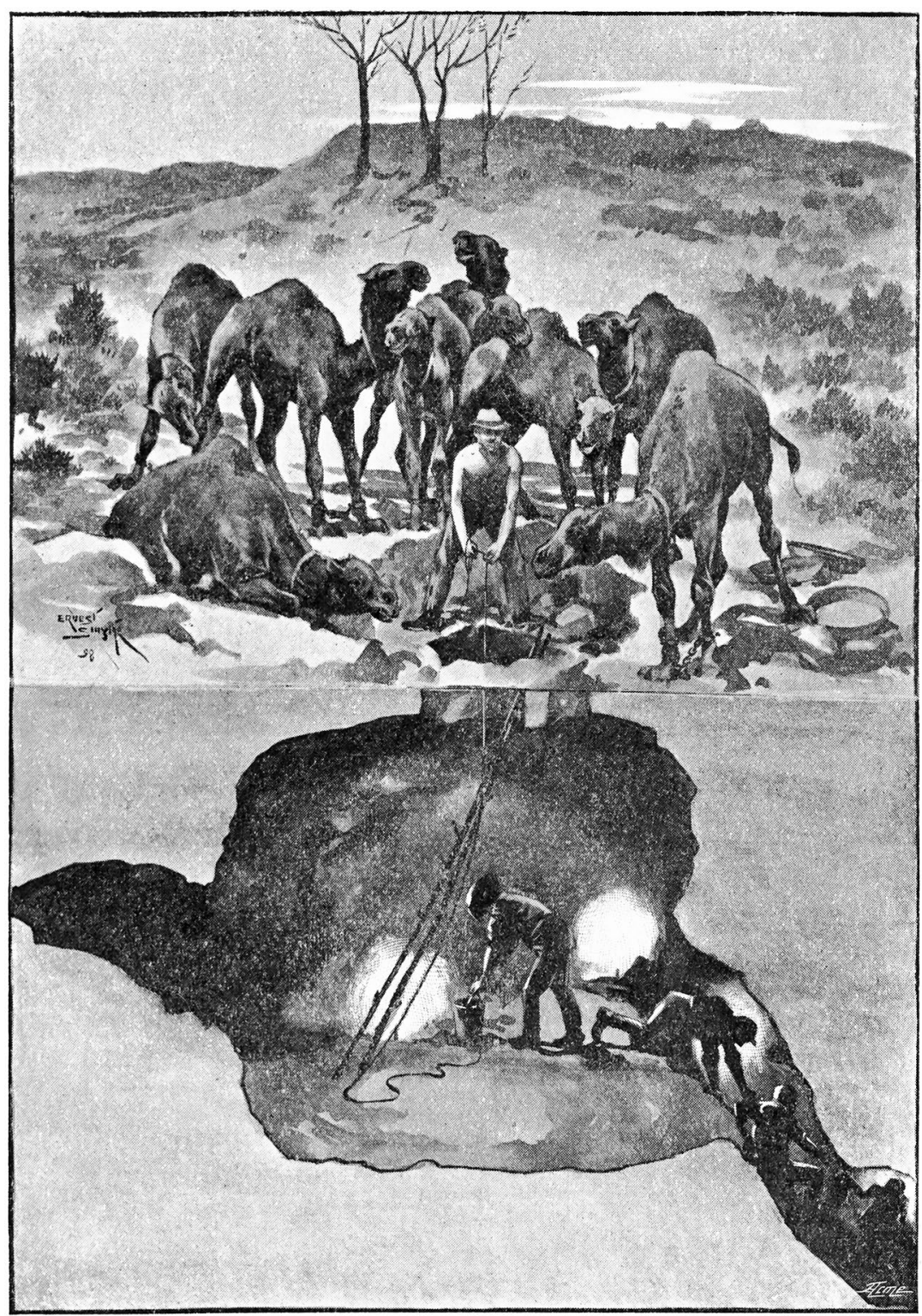

Figure 2.2: 'At work in the cave, Empress Spring'.

Source: Carnegie, Spinifex, 195. 
In early September they again decided to search for an Aboriginal person who could lead them to water, using Warri as a tracker. Eventually, on 11 September, they 'rode right on to [a] camp without warning', and Carnegie captured an older woman who had stopped to save her dingo pups: 'Sorry as I was to be rude to a lady, I had to make her prisoner.' 65 Clearly distressed, she 'shouted, scratching, biting, spitting, and tearing' his skin, 'clutching at every bush' they passed as he carried her along. Upon realising they wanted water, she pointed to a rock hole her camp had been using. However, after his experience with King Billy, Carnegie did not trust her and so tied her up with rope before inspecting the rock hole. After collecting 12 gallons of water, Carnegie was reluctant to give up his captive. Therefore, he:

Decided to take the [woman] back with us, as it had been clear to me for some time past that without the aid of the natives we could not hope to find water. ${ }^{66}$

The explorers returned to their camp and found that the well had dried out, so they dug down and, over the course of four days-working night and day-dug 30 feet below the surface, collecting 140 gallons of water. From digging down that far, Carnegie concluded that 'no rain can have fallen in the district for some number of years ${ }^{67}$ During the next five days, the older woman did not lead them to any new water sources and refused to accept any of their food or water; after repeatedly deeming her 'useless', Carnegie let her loose and was surprised by the 'rapidity' with which she fled. ${ }^{68}$

Carnegie's treatment of the older woman was even more draconian than his treatment of King Billy; even after she had led them to water, he decided to take her with them and, as she 'refus[ed] to walk', he 'roped [her] on to one of the camels [sic] back' ${ }^{69}$ Belying any notion that his capture of Aboriginal people was a desperate survival measure, he came to develop an even more systematic approach, as Aboriginal people, not water, became the primary object of his search. On their next 'hunt', the explorers evidently stalked Aboriginal people before confronting them.

65 Mike Smith argues that, for many desert communities, the dingo is regarded as 'very close family (tjarntu)', as they were used to 'find and run down game, serve as "camp companions"', and as 'sentinels who warned against real and supernatural dangers'. Smith, Archaeology of Australia's Deserts, 208.

66 Carnegie, Spinifex, 232.

67 Carnegie in a letter to John Forrest, extracted in 'Western Australian Exploration', South Australian Register, 25 March 1897, 5.

68 Carnegie, Spinifex, 235.

69 Carnegie, Diaries, vol. 3, 39. 
After tracking an Aboriginal party, the explorers pulled up short on their camels to observe them before 'advancing slowly from opposite directions'. By such methods, the explorers 'were able to get within a hundred yards of [the Aboriginal party] before our silent approach was noticed'. Carnegie exclaimed: 'No words can describe the look of terror and amazement on the faces of those wild savages. ${ }^{70} \mathrm{On}$ another occasion, they rode in on a camp, capturing a man who Carnegie facetiously named Sir John, and ' $[\mathrm{t}]$ ethered $[\mathrm{him}]$ to a ti-tree, with a little fire to cheer him'. When they set out the next day, 28 September, they dragged the reluctant man by his rope to coerce him into action. ${ }^{71}$ This initiated a battle of wills, as Carnegie and his men tried to force the man into leading them to water (at some point, they swapped his rope for chain). Sir John led them to two dry wells, an act that the increasingly suspicious Carnegie thought was deliberate, believing the captive appeared to watch their 'disgust with evident satisfaction'. ${ }^{72}$ In retaliation, Carnegie 'had to resort to the unfailing argument of allowing him no water at all', as he had learned with King Billy that:

Thirst is a terrible thing; it is also a great quickener of the wits, and the result of this harsh treatment, which reduced the poor buck to tears (a most uncommon thing amongst natives), was that before very long we were enabled to unload and make camp in one of the most charming little spots I have ever seen. ${ }^{73}$

Carnegie named the oasis 'Helena Springs'. His success seemed to justify captivity as a means of finding water: 'what chance of finding such a place without the help of those natives to whom alone its existence was known? ${ }^{74} \mathrm{He}$ intended to keep Sir John for a few more days, 'as this is a less tedious method of finding water than following up smokes. ${ }^{75}$ However, during their five days at Helena Springs, Sir John escaped; he used the sharp end of a meat tin to cut the packing bag to which his chain had been secured. As with King Billy, Carnegie maintained that he had admirably compensated his captives for their torture-induced labours; he lamented that Sir John's premature escape prevented him 'return[ing] to his family laden with presents' that were allegedly set aside for him. 
He later rationalised that the 3-foot length of 'light chain on [Sir John's] ankle' might be 'treasured for many years to come' by his tribe; ${ }^{76}$ however, his diary presented a darker account:

So he departed taking his chain with him, how he will remove it from his ankle I have no idea-he tried to burn thro' [sic] the chain one night but found it rather painful—Poor old buck! it [sic] will be a most uncomfortably anklet but he should have waited. ${ }^{77}$

Finding Helena Springs marked a turning point in Carnegie's strategy, as he became even more mercenary and pre-emptive in kidnapping Aboriginal people. Shortly after the expedition resumed, the explorers saw smoke rising nearby and decided to make towards it. As Carnegie explained:

Though we were not in great want of water, I considered it always advisable to let no chance of letting some slip by, since one never can tell how long the next may be in coming. ${ }^{78}$

His plan to capture an Aboriginal 'guide' despite having ample water complicates the historiographical argument that kidnapping was an act of desperation. Instead, kidnapping seems to have become the primary imperative of the expedition-they tracked footprints and smoke across the desert and increasingly seemed to see Aboriginal people as hard-won trophies. On one occasion, after crossing Davenport Hills, they heard the 'distant call' of a woman and saw the smoke from a fire. Carnegie 'despatched Godfrey to surprise the camp', and when Carnegie 'arrived on the scene' he found:

Godfrey standing sentinel beneath a tree, in the branches of which stood at bay a savage of fine proportions. He had a magnificent beard, dark brown piercing eyes, splendid teeth, a distinctly Jewish profile, and no decorations or scars on his chest or body. I shall not forget the colour of his eyes nor their fierce glitter, for I climbed the tree after him, he trying to prevent my ascent by blows from a short, heavy stick which I wrested from him, and then with broken branches of dead mulga, with which he struck my head and hands unmercifully, alternately beating me and prodding me in the face, narrowly missing my eyes. If he suffered any inconvenience by being kept captive afterwards, he well repaid himself beforehand by the unpleasant time he gave me. ${ }^{79}$

76 Carnegie, Spinifex, 273.

77 Carnegie, Diaries, vol. 3, 53.

78 Carnegie, Spinifex, 278.

79 Carnegie, Spinifex, 399. 


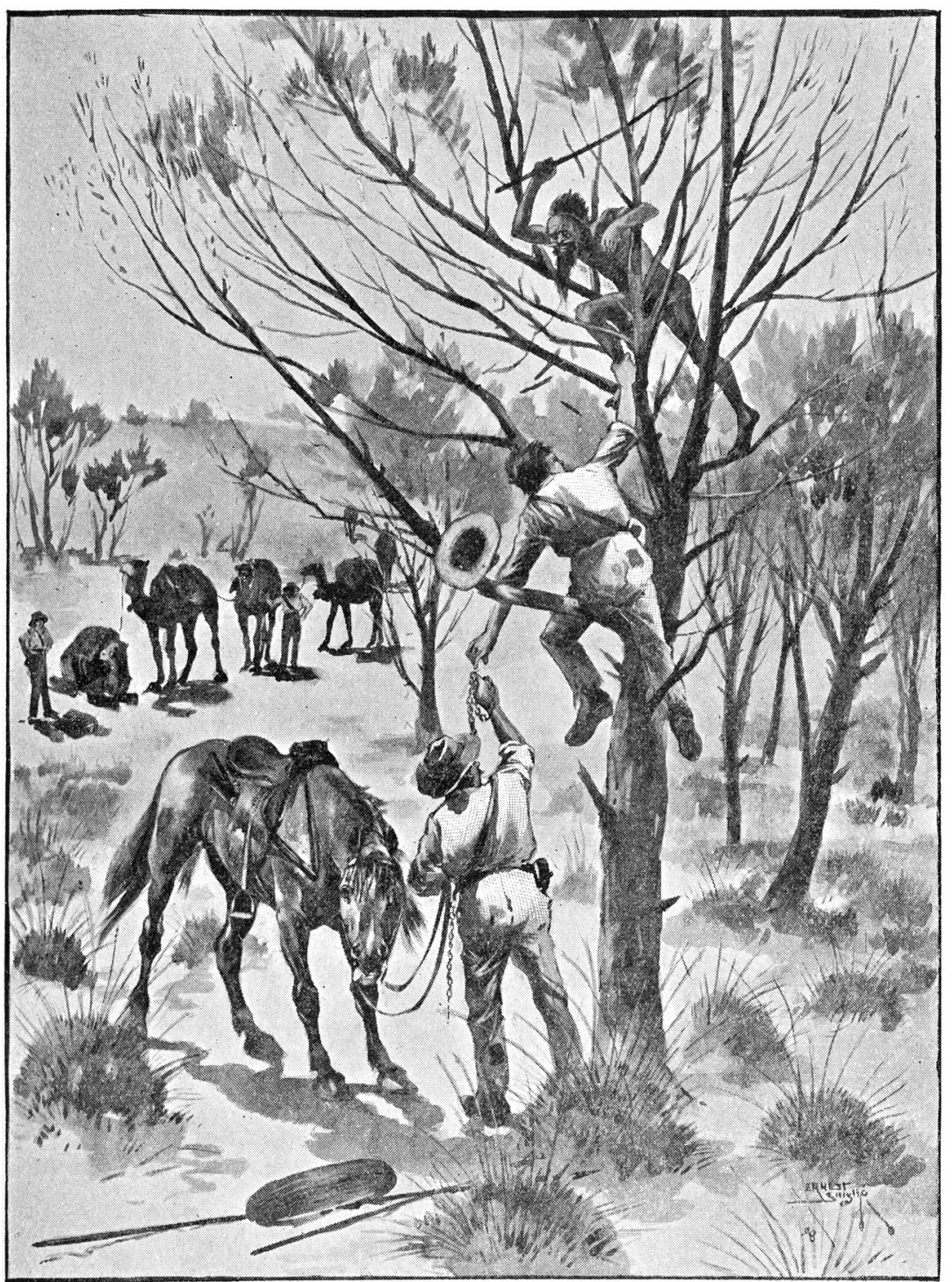

Figure 2.3: 'Establishing friendly relations'.

Source: Carnegie, Spinifex, 401. 
Carnegie's party captured another six Aboriginal people, including women, ${ }^{80}$ as they travelled through the desert, forcing their captives to lead them to water. Yet, on several occasions, it was not evident that such coercive measures were necessary.

In November 1896, when they were about 100 miles shy of Halls Creek, Carnegie's expedition came across 'the biggest camp of natives' they had seen, comprising a 'dozen little "wurlies" or branch-shelters'. At the time, the only occupants were an 'oldish' man, who Carnegie referred to as the 'old Jew', ostensibly due to the shape of his nose, several women and numerous children. Carnegie noticed that a young girl had skin sores, which he dressed with 'tar and oil', and a boy had 'sore eyes, literally eaten away at the inner corners into deep holes'. He 'doctored' the boy, applying a lotion he had brought with him while the old man 'nodded his head in approval'. Immediately after ministering to the patient, Carnegie reported that the family 'showed us their well close by' and, while Carnegie started baling out water, Godfrey 'pressed the old man into our service', making him cut 'bushes for a shade'. ${ }^{81}$ The next day, they were 'greatly entertained by two small boys' who were interested in everything they did and 'were soon tremendous chums with Warri'. One of the boys even 'volunteered to show [Carnegie] a very large water' and led them to a 'nice little pool under a step in the rocky bed'. ${ }^{22}$ While this family 'evidently knew all about a rifle', ${ }^{83}$ so may have offered to lead Carnegie to water as a means of maintaining peace, it is more likely that they did it as a mark of reciprocity for Carnegie's tending to the ill children. Four or five months later, when Carnegie was on his return journey from Halls Creek, he met the old man again. While the explorers were camped near Sturt Creek, 'a fresh mob of blacks came in':

They as soon recognised us, and appeared tremendously pleased. The old Jew patted me, and grinned, and squirmed in a most ludicrous way; I discovered that he was thanking me for having cured his son's eyes—so the lotion had done its work well. ${ }^{84}$

80 Carnegie, Spinifex, 397, 407.

81 Carnegie, Spinifex, 296-97.

82 Carnegie, Spinifex, 301.

83 Carnegie, Spinifex, 297.

84 Carnegie, Spinifex, 373. 
Moreover, they also presented Carnegie with a 'highly treasured' 'flat stick carved all over into rough patterns', which was 'carefully wrapped' and 'given as a mark of respect or gratitude for curing the boy's eyes'. In addition, they gave him 'throwing sticks, balls of hair string, a shield and tomahawk'. ${ }^{85}$ To reciprocate for these gifts, Carnegie gave them 'numerous costly presents from us - one or two old shirts, strips of coloured handkerchief to make sporrans of, a knife or two, and so forth', and they seemed 'perfectly satisfied' ${ }^{86}$ The Aboriginal man's generous gift should have shown Carnegie that he could elicit Aboriginal knowledge of water through displays of kindness and reciprocal exchanges, and not just through violent, coercive means. Yet, within the same month, despite having ample water, Carnegie again kidnapped Aboriginal people:

The country ahead looked so bad that I decided to take the two bucks with us for as long as they knew the waters, so secured the one to the other by the neck, with plenty of spare chain between. ${ }^{87}$

Carnegie's expedition eventually returned to Coolgardie in April 1897 safe and sound, except for the unfortunate Stansmore who accidentally shot himself in November 1896. Carnegie concluded that it 'has been my fate, in all my exploration work, to find none but useless country'. ${ }^{88}$

\section{Conclusion}

Historians have been appalled by Carnegie's strategy of capturing Aboriginal people and yet have rationalised the practice as a desperate means of surviving desert conditions. Such interpretations have been based on passing mentions of only one or two instances in which Carnegie kidnapped people and have not seriously taken into account the 14 Aboriginal men and women he captured and chained over the course of his desert crossing or the dozens of families no doubt traumatised from being hunted by strangers on camel back. In this chapter, I have

85 These gifts perhaps contributed to Carnegie's collection of Aboriginal artefacts, which he later exhibited to a meeting of the Anthropological Institute of Great Britain and Ireland, and seven of which he donated to the British Museum. 'Australia at the Anthropological Institute', The Daily Telegraph (Sydney), 7 May 1898, 11; Carnegie, Spinifex, 227; British Museum, 'David Wynford Carnegie', accessed 6 December 2018, www.britishmuseum.org/research/collection_online/search. aspx?people $=41005 \&$ peoA=41005-3-9.

86 Carnegie, Spinifex, 373.

87 Carnegie, Spinifex, 380.

88 Carnegie, Spinifex, 433. 
considered his water-finding technique within the context of both his personal experiences (the result of his various forays in the desert) and overarching colonial discourses about Indigenous labour. By his own account, it is clear that Carnegie had other means of obtaining water, be it the frustrating and cumbersome use of condensers or through offering reciprocal exchanges with Aboriginal people for water. Yet, after an unexpected and opportunistic encounter with an Aboriginal man who led the explorers to water, Carnegie developed a more systematic, mercenary and pre-emptive strategy of kidnapping Aboriginal people, subjecting them to increasingly brutal incarceration and forcing them to find water for him. He was evidently proud of his systematic and coercive technique for finding water, which he later detailed in a letter to the Western Australian premier, Sir John Forrest, himself an acclaimed explorer of the arid interior:

All through this sandridge country we carry out the one plan of finding water, which was as follows:- For hunting purposes the natives burn large patches of spinifex. The smoke from these fires can be easily seen for some considerable distance, and frequently I have counted as many as five in a day. Choosing a smoke, if possible, on our general course we would steer for it, and when it died down, as it would do in the course of a few hours continue in the same direction till the burnt ground was reached. We would then spread out, pick up the tracks and if possible catch a native. This we were usually fortunate to manage, though only at the expense of great patience and much labour. Often as many as four days would elapse between the time of our sighting the smoke and catching a black. ${ }^{89}$

Carnegie's attitude arguably reflects a broader culture of colonised labour in which Aboriginal people's work and efforts are rendered invisible, masked as either begging or gratitude, and that led to the colonial fantasy that Aboriginal people's labour could only be harnessed through coercive and punitive means. 
Carnegie's increasingly brutal means of kidnapping_or what he called 'nigger catching' ${ }^{\prime 0}$ in a letter to a friend-reflects what anthropologist Gannanath Obeyesekere calls the 'Kurtz syndrome'. Discussing Captain James Cook's increasingly violent and draconian treatment of Pacific Islanders during his second and third voyages of discovery, Obeyesekere explains that Kurtz syndrome, named after the megalomaniac colonial overlord in Joseph Conrad's novella Heart of Darkness, is a myth model in which Europeans 'take on the characteristics of the savage-[that is] the characteristics imputed to the savage by the civiliser's culture'. It lies in opposition to what Obeyesekere calls the 'Prospero syndrome'-the myth that Europeans are 'harbingers of civilisation who remain immune to savage ways'. ${ }^{11}$ Obeyesekere's focus on Cook, a maritime explorer, is significant, since, arguably, the mobile nature of imperial exploration amplifies this Kurtzean mentality: physical isolation and hardship; removal from the ameliorating influence of social and moral protocols; an unpredictability of daily circumstances that exacerbates a desire to assert control; and the presence of 'natives' who can be deemed less than human or, in Carnegie's words, 'more like monkeys than anything else'. ${ }^{92}$ For Carnegie, his initial ambitions of finding both gold and a new route through the desert were supplanted by the more immediate drive to capture and control Aboriginal people. Kidnapping Aboriginal people was not just a desperate means to an end, but also became an end in itself, providing the only excitement in a long, arduous journey through the desert. As Carnegie himself exclaimed about the Western Australian interior: 'What heartbreaking country, monotonous, lifeless, without interest, without excitement save when the stern necessity of finding water forced us to seek out the natives in their primitive camps!'93

90 Letter to Tom Stoddart, a camel trader from the Coolgardie Carrying Company, extracted in 'In Dead Man's Land', Coolgardie Miner, 10 August 1897, 6. His choice of terminology here is significant, and seems intended to dehumanise his Aboriginal captives. In Spinifex and Sand he only uses the term twice, on both occasions in quotes by others; in one case, during his very first expedition, in which he ironically refuted a miner's mother's fears that her son might participate in "nigger hunting excursions" that she heard went on in Western Australia', claiming that 'she need not have disturbed herself, for such things never existed'. Carnegie, Spinifex, 59. However, in his unpublished diaries, he liberally uses this denigratory term, notably beginning around the same time he first kidnaps an Aboriginal man with Gus Luck: prior to this incident, he usually used the term 'native'.

91 Obeyesekere, The Apotheosis of Captain Cook, 11-12.

92 'Through Western Australian Deserts', Clarence and Richmond Examiner, 26 March 1898, 6.

93 Carnegie, Spinifex, 292. 
Carnegie's search for excitement led him away from the Western Australian desert and back to England where he wrote his account of the expedition, Spinifex and Sand: A Narrative of Five Years' Pioneering and Exploration in Western Australia, presented a lecture to the esteemed RGS and was awarded its Gill Medal in $1898 .{ }^{94}$ In 1899 , he moved to northern Nigeria, where he gave up the adventure of exploration for the security of tenured employment to serve as assistant resident under Sir Frederick Lugard. There he practised the lessons in settler manhood that he had learned in Western Australia. While believing he 'treated his black "boys" as friends', Carnegie insisted that 'he was also master'. ${ }^{95}$ Unfortunately for Carnegie, the Nigerians did not share this sentiment and, in November 1900, during his excursions between Koton Kerifi and Tawaré in pursuit of the so-called 'brigand' Mama Gana, he was killed by a poison arrow.

\section{Bibliography}

\section{Primary Sources}

Carnegie, David W. Diaries, 1894-1897 [manuscript], 4 vols, State Library of Western Australia, ACC 2693A.

—. 'Explorations in the Interior of Western Australia: Paper Read to the Society, February 14, 1898', Geographical Journal 11, no. 3 (March 1898): 258-86.

- Spinifex and Sand: A Narrative of Five Years' Pioneering and Exploration in Western Australia. London: CA Pearson, 1898.

Carnegie, Helena M. 'Introduction'. In David W. Carnegie. Letters from Nigeria: Of the Honourable David Wynford Carnegie, F.R.G.S., v-xli. Brechin: Black \& Johnston, 1902.

\section{Secondary Sources}

Baker, Don. 'Wanderers in Eden: Thomas Mitchell Compared with Lewis and Clark'. Aboriginal History 19, no. 1/2 (1995): 3-20.

94 Morison, 'Carnegie, David Wynford (1871-1900)'; Carnegie, 'Explorations in the Interior of Western Australia'.

95 H. M. Carnegie, 'Introduction', xxxv. 
Bayly, I. A. E. 'Review of How Indigenous People Managed for Water in Desert Regions of Australia'. Journal of the Royal Society of Western Australia 82 (1999): 17-25.

Burnett, D. Graham. "“It is Impossible to Make a Step without the Indians": Nineteenth-Century Geographical Exploration and the Amerindians of British Guiana'. Ethnohistory 49, no. 1 (2002): 3-40. doi.org/10.1215/ 00141801-49-1-3.

Cahir, Fred. Black Gold: Aboriginal People on the Goldfields of Victoria, 18501870. Canberra: ANU E Press and Aboriginal History, 2013.

Castle, Robert and Jim Hagan. 'Settlers and the State: The Creation of an Aboriginal Workforce in Australia'. Aboriginal History 22 (1998): 24-35.

Curthoys, Ann. 'Indigenous Dispossession and Pastoral Employment in Western Australia during the Nineteenth Century: Implications for Understanding Colonial Forms of Genocide'. In Genocide on Settler Frontiers: When HunterGatherers and Commercial Stock Farmers Clash, edited by Mohamed Adhikari, 210-31. New York: Berghahn Books, 2014.

Driver, Felix and Lowri Jones. Hidden Histories of Exploration: Researching Geographical Collections. London: Royal Holloway, University of London, and Royal Geographical Society (with IBG), 2002.

Fijn, Natasha, Ian Keen, Christopher Lloyd and Michael Pickering, eds. Indigenous Participation in Australian Economies II: Historical Engagements and Current Enterprises. Canberra: ANU E Press, 2012.

Fritsch, Kathrin. “'You Have Everything Confused and Mixed Up...!": Georg Schweinfurth, Knowledge and Cartography Of Africa in the 19th Century'. History in Africa 36, no. 1 (2002): 87-101.

Goodman, David. 'The Gold Rushes of the 1850s'. In Cambridge History of Australia, edited by Stuart McIntyre and Alison Bashford. 2 Vols, 170-88. Melbourne: Cambridge University Press, 2013. doi.org/10.1017/CHO 9781107445758.010 .

Harman, Kristyn and Elizabeth Grant. "Impossible to Detain without Chains”? The Use of Restraints on Aboriginal People in Policing and Prisons'. History Australia 11, no. 3 (2014): 157-76. doi.org/10.1080/14490854.2014.1166 8538.

Host John and Jill Milroy. 'Towards an Aboriginal Labour History', Studies in Western Australian History 22 (2001): 3-22. 
Keen, Ian, ed. Indigenous Participation in Australian Economies: Historical and Anthropological Perspectives. Canberra: ANU E Press, 2010. doi.org/10.22459/ IPAE.12.2010.

Kennedy, Dane. The Last Blank Spaces. Cambridge: Harvard University Press, 2013. doi.org/10.4159/harvard.9780674074972.

Konishi, Shino. The Aboriginal Male in the Enlightenment World. London: Pickering and Chatto, 2012.

Konishi, Shino, Maria Nugent and Tiffany Shellam, eds. Indigenous Intermediaries: New Perspectives on the Exploration Archives. Canberra: ANU Press and Aboriginal History, 2015. doi.org/10.22459/II.09.2015.

Morison, Patricia. 'Carnegie, David Wynford (1871-1900)'. Australian Dictionary of Biography, National Centre of Biography, Australian National University, 1979, accessed 12 June 2017, adb.anu.edu.au/biography/carnegiedavid-wynford-5509/text9377.

Obeyesekere, Gananath. The Apotheosis of Captain Cook: European Mythmaking in the Pacific. Princeton: Princeton University Press, 1997.

Peasley, William John. In the Hands of Providence: The Desert Journeys of David Carnegie. Carlisle, WA: Hesperian Press, 2013.

Reynolds, Henry. 'The Land, the Explorers and the Aborigines'. Australian Historical Studies 19, no. 75 (1980): 213-26.

Robinson, Shirleene. 'The Unregulated Employment of Aboriginal Children in Queensland, 1842-1902'. Labour History 82 (2002): 1-15. doi.org/10.2307/ 27516838 .

Russell, Lynette. “'Tickpen”, “Boro Boro”: Aboriginal Economic Engagements in Early Melbourne'. In Settler Colonial Governance in Nineteenth-Century Victoria, edited by Lynette Russell and Leigh Boucher, 27-46. Canberra: ANU Press and Aboriginal History, 2015. doi.org/10.22459/SCGNCV.04. 2015.01.

Shellam, Tiffany, Maria Nugent, Shino Konishi and Allison Cadzow, eds. Brokers and Boundaries: Colonial Exploration in Indigenous Territory. Canberra: ANU Press and Aboriginal History, 2016. doi.org/10.22459/BB.04.2016.

Simpson, Pat. 'Bayley, Arthur Wellesley (1865-1896)'. Australian Dictionary of Biography, National Centre of Biography, Australian National University, 1979, accessed 9 June 2017, adb.anu.edu.au/biography/bayley-arthur-wellesley-88/ text8665. 
Smith, Mike. The Archaeology of Australia's Deserts. New York: Cambridge University Press, 2013. doi.org/10.1017/CBO9781139023016.

Stoddart, D. R. "The RGS and the "New Geography": Changing Aims and Changing Roles in Nineteenth Century Science'. The Geographical Journal 146, no. 2 (1980): 190-202. doi.org/10.2307/632860.

Strauss, Kendra. 'Coerced, Forced, and Unfree Labour: Geographies of Exploitation in Contemporary Labour Markets'. Geography Compass 6, no. 3 (2012): 137-48. doi.org/10.1111/j.1749-8198.2011.00474.x.

Thorpe, Bill. Colonial Queensland: Perspectives on a Frontier Society. St Lucia: University of Queensland Press, 1996.

Williams, Claire and Bill Thorpe. Beyond Industrial Sociology, North Sydney: Allen and Unwin: 1992.

Winter, Sean. 'Coerced Labour in Western Australia during the Nineteenth Century'. Australasian Historical Archaeology 34 (2016): 3-12.

Woollacott, Angela. 'Frontier Violence and Settler Manhood'. History Australia 6, no. 1 (2009): 1-11. doi.org/10.2104/ha090011.

\section{Newspapers}

Clarence and Richmond Examiner

Coolgardie Miner

The Daily Telegraph (Sydney)

Kalgoorlie Miner

Kalgoorlie Western Argus

South Australian Register 
This text is taken from Labour Lines and Colonial Power: Indigenous and Pacific Islander Labour Mobility in Australia, edited by Victoria Stead and Jon Altman, published 2019 by ANU Press, The Australian National University, Canberra, Australia.

doi.org/10.22459/LLCP.2019.02 